\title{
Early Bronze Age Plain Simple Wares (Tripod Vessels) of Tilbeshar (Turkey): Archaeometric Characterization
}

\author{
Murat BAYAZITT ${ }^{*}$, Didem ÇAĞİNE², Elif GENÇ³ \\ ${ }^{1}$ Batman University, Department of Ceramics, Batman, Turkey \\ ${ }^{2}$ Batman University, Department of Archaeometry (Master Program/Student), Batman, Turkey \\ ${ }^{3}$ Çukurova University, Department of Archaeology, Adana, Turkey \\ (ORCID: 0000-0003-1453-249X) (ORCID: 0000-0002-3988-1402) (ORCID: 0000-0003-0508-7267)
}

\begin{abstract}
The present study reports the results obtained through an archaeometric investigation on representative Early Bronze Age tripod vessels belonging to plain simple wares of Tilbeshar which is located almost $32 \mathrm{~km}$ southeast of Gaziantep (Turkey). The samples were characterized by XRD (X-ray diffraction), thin section (optical microscopy), FTIR (Fourier Transformed Infrared Spectroscopy), TG-DTA (Thermogravimetric Differential Thermal Analysis) and SEM/EDX (scanning electron microcopy/energy dispersive X-ray spectroscopy). The chemical composition of the samples showed that the potsherds possessed high amount of $\mathrm{CaO}$ indicating use of calcareous clays. Proving this data XRD, TG-DTA and FTIR analyses revealed the presence of calcite, as well. Considering the mineral/phase contents of the samples, the firing temperature of the potsherds was found to change in the range of $700-900^{\circ} \mathrm{C}$. The appearance of neo-formations for most of the samples suggested a firing temperature range of $800-900^{\circ} \mathrm{C}$ for such potsherds. SEM images of the samples showed that there was a very low partial vitrification for some of the samples, while it was not observed for the others. This observation approved the firing temperature ranges of the samples. Petrography results suggested that the main rock type for the potsherds was basalt (igneous rock) and the raw materials likely originated from mafic rocks. Taking into account the whole data and the geological formation of the region, it was predicted that the potsherds likely belonged to a local production.
\end{abstract}

Keywords: Archaeometry, Spectroscopy, Characterization, Ceramic, Tilbeshar (Turkey).

\section{Tilbaşar Erken Tunç Çağı Yalın Basit Üç Ayakı Kapları: Arkeometrik Karakterizasyon}

\begin{abstract}
$\ddot{O} \mathbf{z}$
Bu çalışma Gaziantep ilinin yaklaşık 32 km güneydoğusunda yer alan Tilbaşar'da ele geçen temsili Erken Tunç Çağı yalın basit seramiklerin (üç ayaklı kap parçalarının) arkeometrik incelemesinde ele geçen sonuçları sunmaktadır. Örnekler X-ışını difraksiyonu (XRD), ince kesit (petrografi), Fourier dönüşümlü kızılötesi (FTIR) spektroskopisi, termogravimetrik-diferansiyel termal analiz (TG-DTA) ve taramalı elektron mikroskobu/enerji saçınımlı X-ışını spektroskopisi (SEM-EDX) ile karakterize edilmiştir. Örneklerin kimyasal kompozisyonları bu seramiklerin yüksek oranda $\mathrm{CaO}$ içerdiğine ve kalkerli killerin kullanıldığına işaret etmiştir. XRD, TG-DTA ve FTIR analizleri de bu sonucu teyit edecek biçimde kalsit varlığını ortaya koymuştur. Örneklerin mineral/faz içerikleri dikkate alınarak seramiklerin pişirim sıcaklıklarının $700-900^{\circ} \mathrm{C}$ arasında değiştiği bulunmuş̧ur. Birçok örnekte görülen yeni oluşum fazları ise bu tip seramikler için $800-900^{\circ} \mathrm{C}$ pişirim aralığına işaret etmiştir. Numunelere ait SEM görüntüleri bazı seramiklerde düşük bölgesel vitrifikasyonun olduğunu, diğerlerinde ise olmadığını göstermiştir. Bu sonuç seramiklerin pişirim sıcaklıklarını teyit eder nitelikte olmuştur. Petrografi sonuçları seramiklerdeki kayaç tipinin bazalt (volkanik kayaç türü) olduğunu ve hammaddelerin büyük olasılıkla mafik kayaç kökenli olduğuna işaret etmiş̧tir. Tüm veriler ve bölgenin jeolojik oluşumları dikkate alındığında, seramiklerin büyük ihtimalle yerel üretime ait olduğu öngörülmüştür.
\end{abstract}

Anahtar kelimeler: Arkeometri, Spektroskopi, Karakterizasyon, Seramik, Tilbaşar.

*Sorumlu yazar: m.bayazit@hotmail.com

Geliş Tarihi: 10.01.2019Kabul Tarihi: 09.05.2019 


\section{Introduction}

Tilbeshar Mound is located almost $32 \mathrm{~km}$ southeast of Gaziantep (Turkey) (Figure 1) [1,2]. It is approximately $12 \mathrm{~km}$ to Oğuzeli district, near the village of Gündoğan. The mound has the height of $40 \mathrm{~m}$ and size of 6ha, while the down town spreading to the north and south is 2-7 $\mathrm{m}$ in height and 56ha in size. Tilbeshar is one of the biggest settlements of the region with it's up and down towns. The mound has been discovered by an Italian crew in 1971, then the excavations and the archaeological surveys continued till 2006 under the authorization of Gaziantep Museum Directorate and Christine Kepinski Lecomte. After a nine-year break, in 2015, the work restarted under the authorization of Gaziantep Museum Directorate and scientific responsibility of Assist. Prof. Dr. Elif Genç (Çukurova University, Department of Archaeology, Turkey). Tilbeshar is one of the biggest settlements in the region providing a significant knowledge to the northern Syria and southeastern Anatolia archaeology. Furthermore, some parts of the mound will be flooded as the Doğanpinar Dam goes in action. Therefore, both the archaeological and archaeometric studies are believed to be mandatory in terms of enlightening the cultural and social characteristics of the region $[1,3]$.

Archaeometric investigations provide a substantial knowledge regarding the production technologies of the archaeological findings belonging to the past civilizations, and therefore about their social, economic, cultural etc. features, by gathering the branches of nature and engineering sciences which create a multidisciplinary working principle. Ceramics are one of the most intensely encountered artifacts in archaeological excavations, and their characterization provides convenient knowledge in determination of technological level and skills of the civilizations. There are various analysis techniques frequently employed for ceramic findings which generally covers the chemical and mineralogical characterization [4-8].

The present study, which is one of the first detailed investigation of Early Bronze Age plain simple wares (tripod vessels) of Tilbeshar in an archaeometric way, covers the application of spectroscopic (X-ray diffraction; XRD, energy dispersive X-ray spectroscopy; EDX, Fourier transformed infrared spectroscopy; FTIR), microscopic (scanning electron microcopy; SEM, petrography) and thermal (thermogravimetric-differential thermal analysis; TG-DTA) methods. It was aimed to enlighten the raw material content and production properties of the mentioned ceramic group in detail.

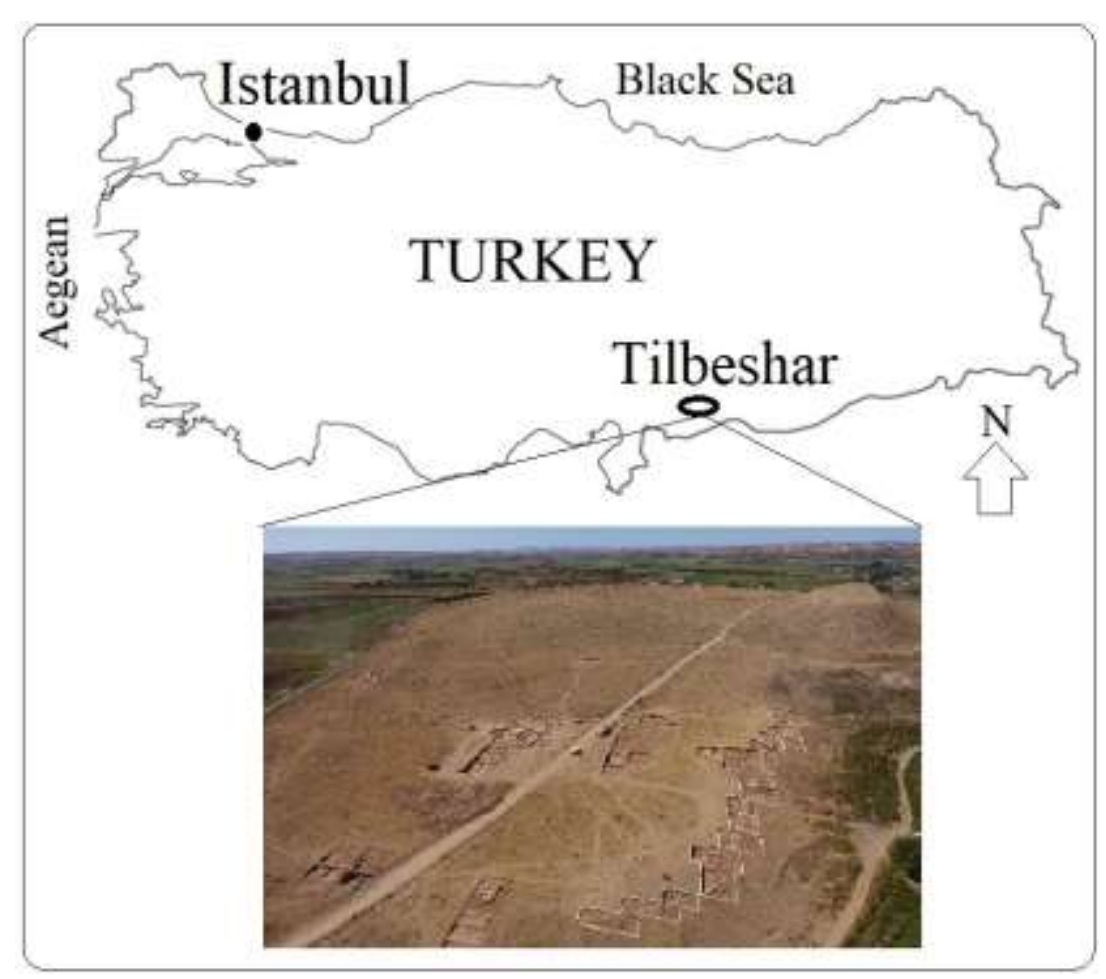

Figure 1. Location of Tilbeshar and its general view [2] 


\section{Experimental}

\subsection{Sampling}

In archaeometric studies, there are generally two different ways of sampling. In the first one, a great number of samples could be selected and only few analyses might be applied in order to differentiate the numerous samples of the set. For instance, chemical composition of the potsherds can be determined by XRF, inductively coupled plasma (ICP) spectroscopy or atomic absorption spectroscopy (AAS), and the samples could be roughly classified according to their chemical contents. In the second one, a relatively lesser amount of samples could be analyzed by means of multi analytical analysis methods which would bring different perspectives in terms of elucidating the diagnostic properties of the potsherds (e.g. mineralogy, micro chemical and micro structural features, coloring agents, organic matters or other additives etc.). The latter sampling process may require additional time, budget and labor, whereas the former one needs less. Whilst, both methods are convenient in ceramic archaeometry (considering the number and characteristics of the ceramics in the whole repertoire), the second one was applied in the present study in order to thoroughly investigate the ceramic group, because it was seen that the potsherds were repeating themselves. Therefore, seven samples, which eminently represented the whole group of such ceramics, were carefully selected by the head of the excavation (Assist. Prof. Dr. Elif Genç, Çukurova University, Turkey) according to their archaeological description, color and form (Figure 2, Table 1).

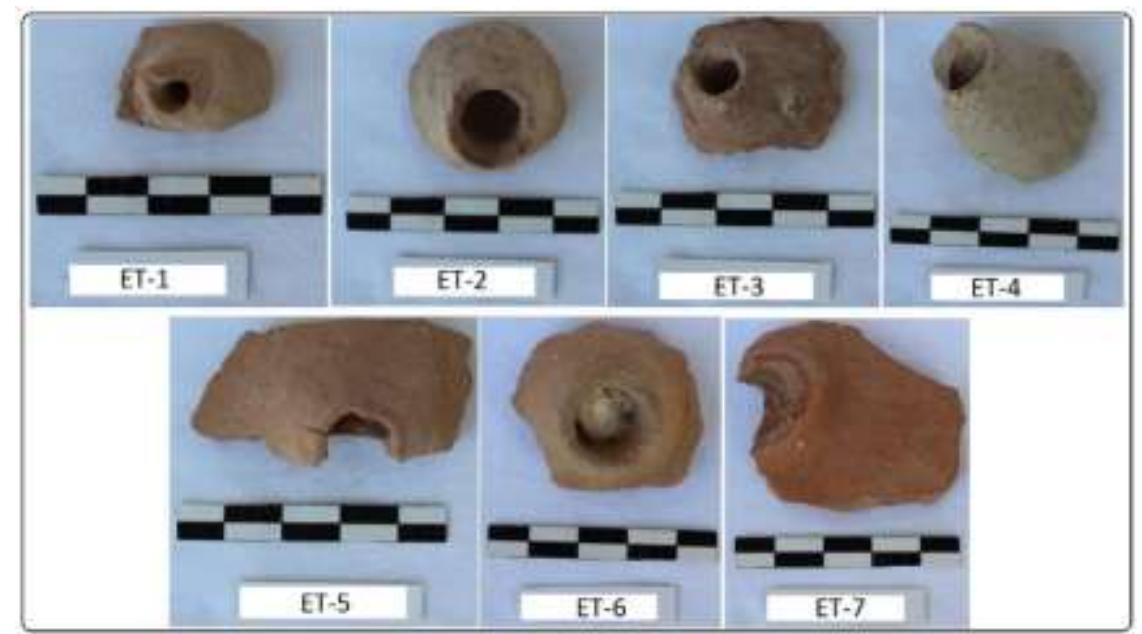

Figure 2. Plain simple wares (tripod vessels) of Tilbeshar characterized in the study

Table 1. Description of the samples

\begin{tabular}{lccccc}
\hline Sample & Visible color & L* & $\mathrm{a}^{*}$ & $\mathrm{~b}^{*}$ & Equivalent color \\
\hline ET-1 & Dark buff/light brown & 37,6870 & 11,7668 & 18,7447 & \\
ET-2 & Light buff & 32,7626 & 5,9546 & 17,3295 & \\
ET-3 & Red/brown & 31,4198 & 13,8261 & 20,7365 & \\
ET-4 & Greenish/buff & 36,9957 & 4,2223 & 14,4845 & \\
ET-5 & Red/brown & 21,9986 & 9,3987 & 14,2212 & \\
ET-6 & Buff/light brown & 16,3986 & 4,5546 & 8,3151 & \\
ET-7 & Red/brown & 26,2947 & 18,5604 & 23,4525 & \\
\hline
\end{tabular}

* White/black (L: 0/100), green (a: 0/-60), red (a: 0/+60), blue (b: 0/-60), yellow (b: 0/+60). 
The representative samples were exposed to a purification process at which the contaminations were removed from the surface of the potsherds after soaking them in distilled water. Powder samples were prepared in a porcelain mortar to be used in destructive techniques requiring powder, and bulk samples were taken for the microscopic analyses.

\subsection{Methods}

In accordance with the mentioned sampling method, the samples were thoroughly characterized using multiple analysis techniques. The minerals and phases were examined using a Panalytical, Empyrean model of XRD. The analysis was carried out in the range of $5-70^{\circ} 2 \theta$ with a Goniometry rate of $2 \% \mathrm{~min}$. The paste features of the potsherds were investigated trough a LEICA Research Polarizan (DMLP model) optical microscopy. Point Counting method was employed to determine the minerals and rock types. A Leica DFC-280 digital camera having a magnification of x25 and single/double nicol was utilized and the results were criticized through the Leica Qwin digital imaging. FTIR analyses were applied with a Perkin Elmer-Spectrum 100 FTIR device which scanned the samples in the range of 400$2000 \mathrm{~cm}^{-1}$. A Shimadzu (DTG-60H model) TG-DTA was used for the thermal analysis. The samples were heated from $25^{\circ} \mathrm{C}$ to $1000^{\circ} \mathrm{C}$ in $\mathrm{N}_{2}$ gas atmosphere within a platinum capsule with a flow rate of $20 \mathrm{ml} / \mathrm{min}$ and heating rate of $20^{\circ} \mathrm{C} / \mathrm{min}$. The micro chemical and micro structural properties of the potsherds were examined by a Carl Zeiss (Supra 40VP model) SEM/EDX. The samples were initially coated with platinum using a Qourum (Q150R ES model) coating device in order to make them conductive so as to shot high quality images in micron scales. EDX results were used in oxide forms (wt.) converted from the elemental concentrations (at. \%), which is conventionally applied as in the available literature. The colors of the samples $(\mathrm{L}, \mathrm{a}, \mathrm{b})$ were examined through a ColorQA Pro SystemIII device using the Commission Internationale de L'Eclairage

\section{Results}

\subsection{SEM-EDX results}

The chemical composition of the samples was evaluated through the EDX results obtained from $100 \mu \mathrm{m}$ scaled SEM images. The results (Table 2) in oxide form (wt. \%) were conventionally transformed from the elemental concentrations (at. \%). The results showed that $\mathrm{CaO}$ was relatively in higher amounts changing in the range of 14.05-41.34 wt. \%. Its quantity was found extremely higher for the sample ET4 which was attributed to the fact that the carbonates (e.g. calcite, dolomite etc.) would have randomly dispersed in the paste and/or the grain size of such minerals would be so coarse that would affect the chemical composition of the selected area. As is known, EDX analysis can be employed on cross sectional areas, points or through a line selected on the image. Therefore, the distribution of the minerals (heterogeneous or homogenous) may significantly cause a fluctuation in chemical composition. Considering this assumption, high amount of $\mathrm{CaO}$ indicated use of calcareous materials in production of the potsherds. $\mathrm{MgO}$ was also found in the range of 1.70-4.06 wt. \% suggesting probable existence of dolomitic materials, as well. This results showed that the origin of the starting materials would be also the $\mathrm{Mg}$ bearing minerals which were thought to be the carbonates (i.e. dolomite) and/or the clay minerals.

Being thought to be originated mainly from quartz and secondly the clay minerals, $\mathrm{SiO}_{2}$ was found in the range of 37.51-52.02 wt. \%. $\mathrm{Al}_{2} \mathrm{O}_{3}$ was found as 12.88-16.69 wt. \%. Such amounts suggested low clay content for the potsherds. This assumption seemed compatible with the relatively higher amounts of $\mathrm{CaO}$ and occasionally $\mathrm{MgO} . \mathrm{K}_{2} \mathrm{O}$ was detected for five samples in the range of 0.521.59 wt. \%, whereas $\mathrm{Na}_{2} \mathrm{O}$ was detected for only one sample (ET-7, 1.22 wt. \%). The presence of $\mathrm{K}_{2} \mathrm{O}$ and $\mathrm{Na}_{2} \mathrm{O}$ was assigned to $\mathrm{K}$-feldspars and plagioclases. $\mathrm{FeO}$ was found changing from 5.83 to 14.52 wt. \% which was thought to be the natural colorant for the potsherds providing the colors of red, buff, brown (in oxidizing environment) or gray, black (in reducing environment) [9]. The whole data obtained by EDX suggested use of calcareous clay batches, in general, and this result implied that the potters likely have supplied the starting raw materials from the near vicinity in the region, because the geological formations of the region matched with the chemical composition and therefore with the probable mineralogical contents of the potsherds [10-16]. 
Table 2. EDX results of the samples

\begin{tabular}{lccccccc}
\hline & \multicolumn{7}{c}{ Oxide } \\
\cline { 2 - 8 } Code & $\mathrm{SiO}_{2}$ & $\mathrm{CaO}$ & $\mathrm{Al}_{2} \mathrm{O}_{3}$ & $\mathrm{FeO}$ & $\mathrm{MgO}$ & $\mathrm{K}_{2} \mathrm{O}$ & $\mathrm{Na}_{2} \mathrm{O}$ \\
\cline { 2 - 8 } ET-1 & 52.02 & 17.50 & 15.36 & 10.25 & 4.06 & 0.81 & - \\
ET-2 & 49.96 & 20.90 & 15.08 & 9.42 & 3.04 & 1.59 & - \\
ET-3 & 49.83 & 15.99 & 16.69 & 14.52 & 1.78 & 1.19 & - \\
ET-4 & 37.51 & 41.34 & 12.88 & 6.57 & 1.70 & - & - \\
ET-5 & 54.78 & 14.05 & 15.47 & 12.35 & 2.82 & 0.52 & - \\
ET-6 & 48.55 & 27.03 & 14.08 & 5.83 & 3.46 & 1.05 & - \\
ET-7 & 51.22 & 19.48 & 16.36 & 9.60 & 2.12 & - & 1.22 \\
\hline
\end{tabular}

SEM images showed that there was a limited vitrification and occasionally partial vitrification for some of the samples (Figure 3 and Figure 4). Considering the high amounts of $\mathrm{CaO}$ together with lower amounts of $\mathrm{K}_{2} \mathrm{O}$ and $\mathrm{Na}_{2} \mathrm{O}$, it was predicted that carbonates would have acted as a flux agent and might have led to a partial vitrification behavior throughout the ceramic matrices of some potsherds. This situation can be seen on SEM images of the samples which occasionally possess evidences of glassy surfaces arranged with the secondary pores (see Figure 3d, Figure $4 \mathrm{~b}$ and Figure 4c). The sectional chemical analyses carried out on various areas throughout the ceramic paste revealed the clear presence of minerals (e.g. quartz, calcite, clay). For instance, Figure 5 shows the traces of calcareous clay rich in iron for the samples ET-1 and ET-2, whereas Figure 6 shows the quartz grain embedded in the ceramic.
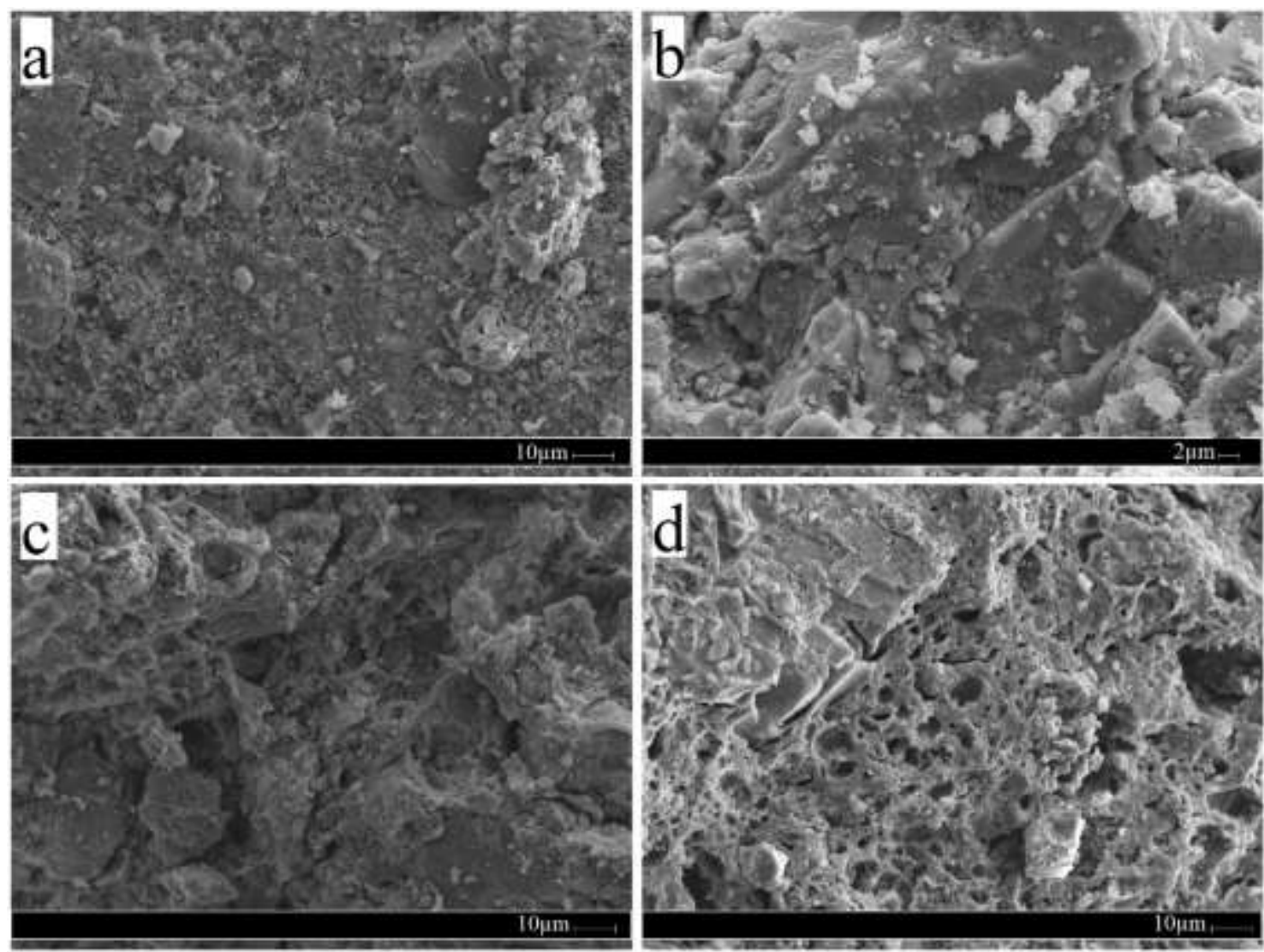

Figure 3. SEM image of the sample (a) ET-1, (b) ET-2, (c) ET-3 and (d) ET-4 

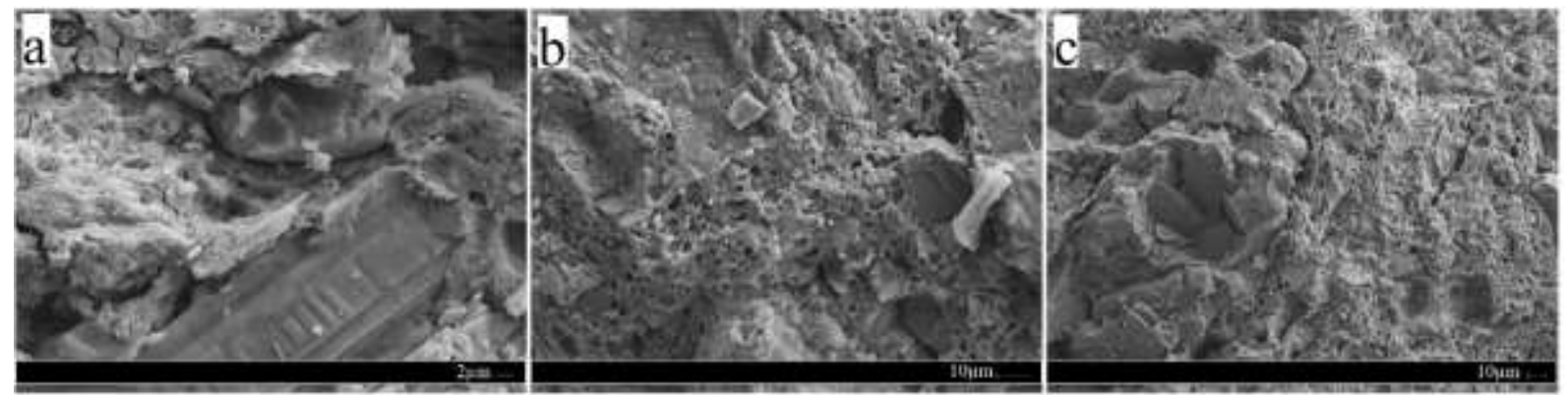

Figure 4. SEM image of the sample (a) ET-5, (b) ET-6 and (c) ET-7
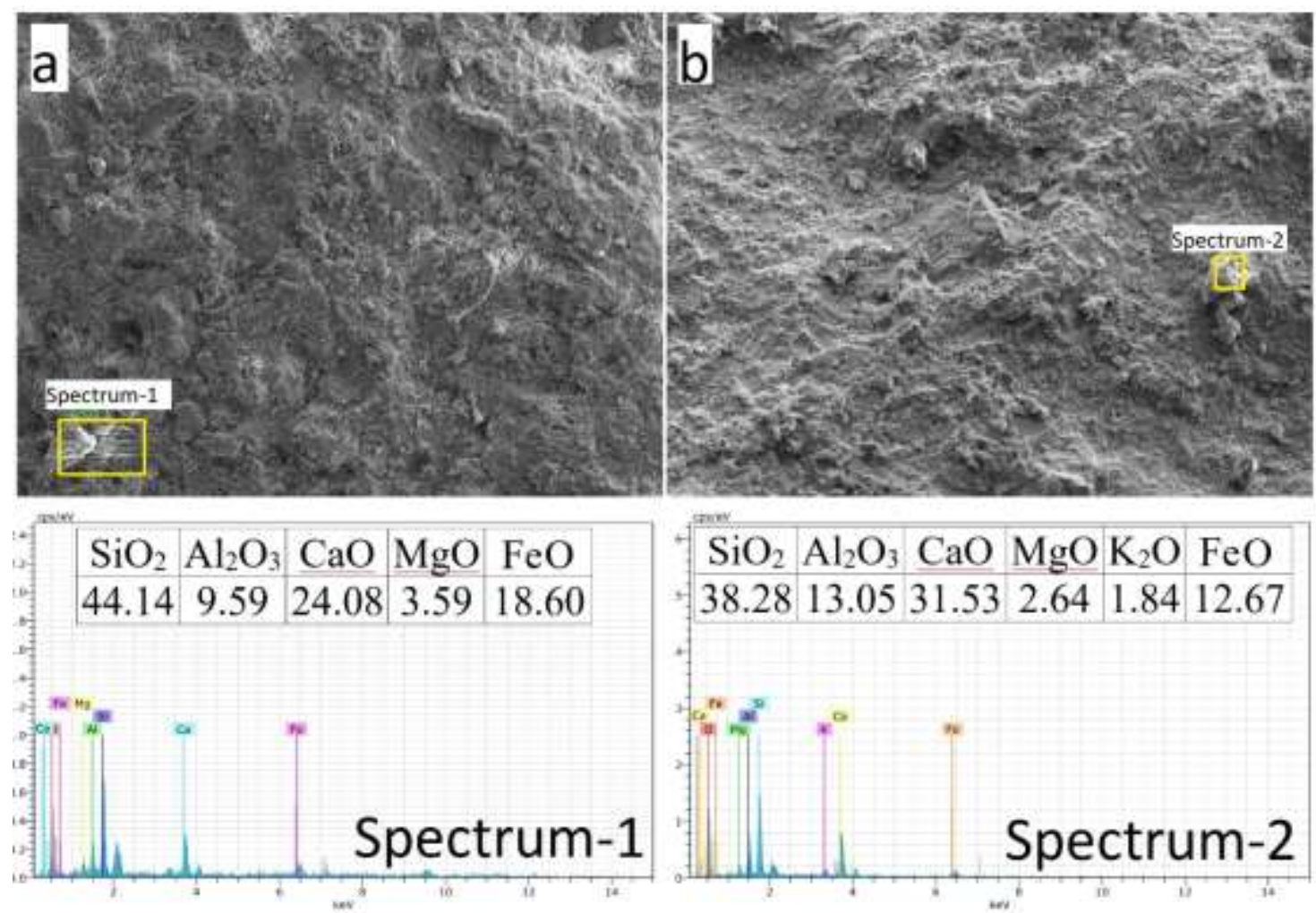

Figure 5. EDX result of the selected area on SEM image of the sample (a) ET-1 and (b) ET-2
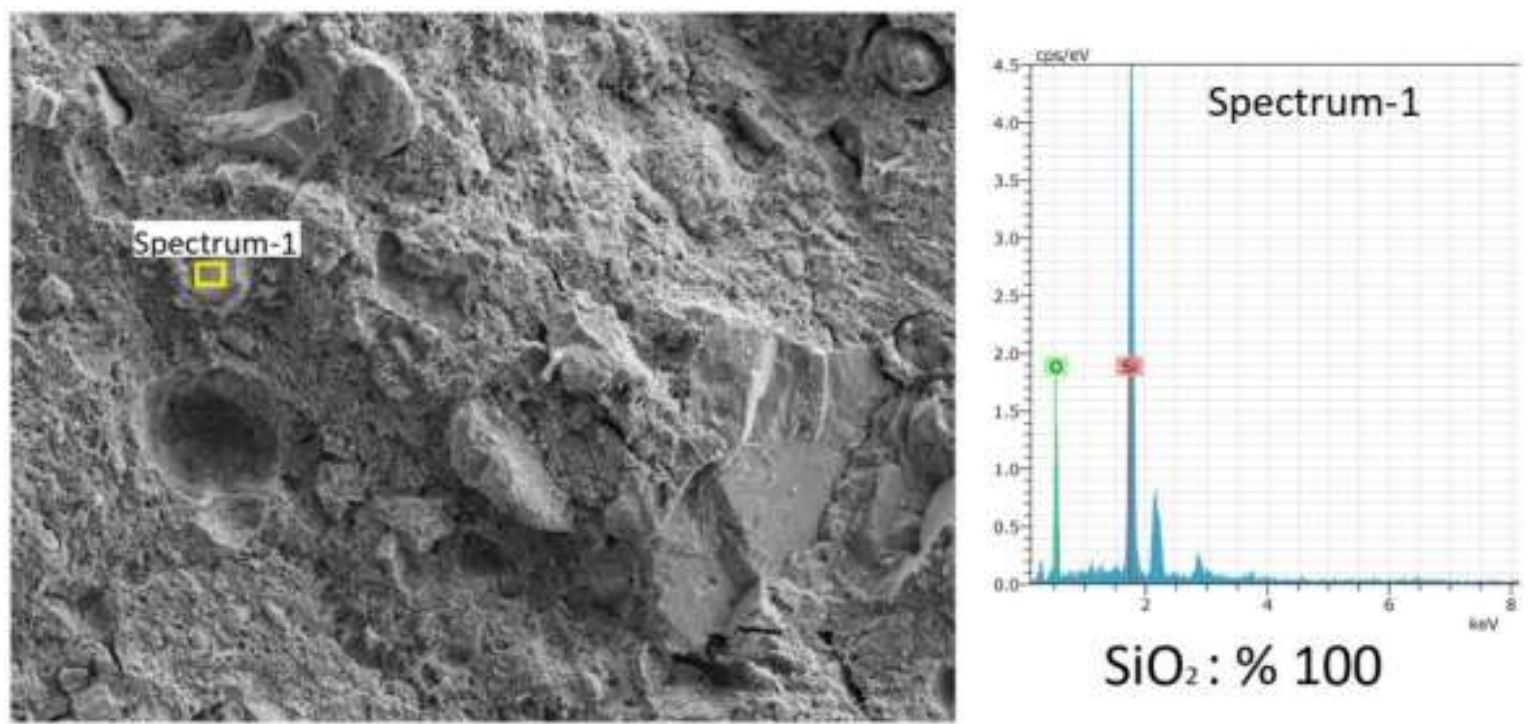

Figure 6. EDX result of the selected area on SEM image of the sample ET-6 


\subsection{Mineralogical content}

\subsubsection{XRD and FTIR results}

XRD and petrography were employed to reveal the mineral/phase and mineral/rock contents of the samples, respectively. In addition, FTIR results are also given in this section in order to thoroughly reveal the minerals. XRD results (Table 3) showed that calcite was abundant in the potsherds and it was the major mineral for most of the samples. This result indicated that calcareous raw materials should have been used in production, which was formerly predicted through the EDX data (see Table 2). Quartz and feldspar/plagioclase were detected for the whole sample set, while clay minerals (illite/muscovite) were seen to be present mostly in trace or scarce amounts except the samples ET-1 and ET-3. As is known, clay minerals decompose in two steps; $i$ : losing the $\mathrm{OH}^{-}$group around $700^{\circ} \mathrm{C}$, ii: full decomposition at about $900^{\circ} \mathrm{C}[17,18]$. High temperature minerals may also occur at sufficient temperatures in the ceramic matrix consisting of carbonates (gehlenite at $\sim 800-850^{\circ} \mathrm{C}$, pyroxene at $\sim 850$ $\left.900^{\circ} \mathrm{C}\right)[17]$.

Table 3. XRD results of the samples

\begin{tabular}{|c|c|c|c|c|c|c|c|c|}
\hline \multirow[b]{2}{*}{ Sample } & \multicolumn{7}{|c|}{ Mineral/Phase* } & \multirow[b]{2}{*}{$\begin{array}{l}\text { Estimated firing } \\
\text { temperature }\left({ }^{\circ} \mathrm{C}\right)\end{array}$} \\
\hline & Q & $\mathrm{Cc}$ & $\mathrm{Fs} / \mathrm{Pl}$ & $\mathrm{I} / \mathrm{M}$ & Gh & $\operatorname{Pr}$ & $\mathrm{H}$ & \\
\hline ET-1 & ++++ & ++ & ++ & + & + & + & + & $850-900$ \\
\hline ET-2 & +++ & ++++ & +++ & $\mathrm{sc}$ & ++ & + & + & $800-900$ \\
\hline ET-3 & ++ & ++++ & ++ & + & $\operatorname{tr}$ & $\mathrm{sc}$ & $\mathrm{sc}$ & $750-850$ \\
\hline ET-4 & ++ & +++ & + & $\mathrm{sc}$ & ++++ & + & $\operatorname{tr}$ & $850-900$ \\
\hline ET-5 & ++ & ++++ & + & $\operatorname{tr}$ & - & - & - & $700-800$ \\
\hline ET-6 & ++ & ++++ & + & $\mathrm{sc}$ & + & $\mathrm{sc}$ & - & $800-850$ \\
\hline ET-7 & ++++ & +++ & ++ & $\mathrm{sc}$ & + & $\mathrm{sc}$ & + & $800-850$ \\
\hline
\end{tabular}

+: Relative abundance (according to intensity/counts; cps), sc: scarce, tr: trace, (-): not defined. * Q: quartz, Cc: calcite, Fs/Pl: feldspar/plagioclase, I/M: illite/muscovite, Gh: gehlenite, Pr: pyroxene, H: hematite.

In the present study, neo-formations (i.e. gehlenite and pyroxene) were obviously detected for some of the samples, and sometimes in trace or scarce amounts (except the sample ET-5). Considering the presence, absence and/or abundance of the minerals, the firing temperature of the samples was found to change in the range of $700-900^{\circ} \mathrm{C}$. The lowest firing temperature $\left(700-800^{\circ} \mathrm{C}\right)$ was estimated for the sample ET-5 which was dominantly comprised of calcite and did not contain any high-temperature phases, whereas the highest firing temperature $\left(850-900^{\circ} \mathrm{C}\right)$ was estimated for the sample ET-1 and ET4 which showed the clear presence of gehlenite and pyroxene. The co-existence of the calcite and neoformations was attributed to an uneven firing process by which the heating rate and/or soaking time would have been inconsistent. The size and distribution of the minerals should also be taken into account at this point. Additionally, primary and secondary calcite should be differentiated. For instance, secondary calcite was detected on FTIR spectrum of the sample ET-1 (Figure 7a) with the band value of $1451.01 \mathrm{~cm}^{-1}$, while the primary calcite showed an IR spectrum at lower values between $1414 \mathrm{~cm}^{-1}$ and $1427 \mathrm{~cm}^{-1}$ (e.g. ET-7, Figure 7b) [19,20].

Other minerals were also observed through FTIR analysis (Table 4). Clay minerals were detected with the bands between $996 \mathrm{~cm}^{-1}$ and $1018 \mathrm{~cm}^{-1}$ (which also occasionally suggested the existence of feldspars and plagioclases), whereas $461 \mathrm{~cm}^{-1}$ and $463 \mathrm{~cm}^{-1}$ were assigned to both the clay minerals/feldspars and pyroxene [21-23]. As is seen, some band values showed an overlapping on minerals' IR spectra, yet XRD results were helpful to make a conclusion. Namely, since the bands near $460 \mathrm{~cm}^{-1}$ indicated to Si-O and Al-O deformations [24], the samples possessing IR spectra around this band (the whole samples set except ET-5) were thought to include high temperature phases, and this result was consistent with XRD data which revealed the presence of the minerals belonging to the melilite and pyroxene groups for such samples (even in trace or scarce amounts, see Table 3). Another overlapping band was $970 \mathrm{~cm}^{-1}$ (sample ET-4) which indicated to pyroxene and wollastonite [25,26]. Since wollastonite was not detected on XRD pattern of this sample, the band was attributed to pyroxene. Quartz was seen with its characteristic IR bands around $694 \mathrm{~cm}^{-1}, 777 \mathrm{~cm}^{-1}$ and $797 \mathrm{~cm}^{-1}$ [21,23]. Iron minerals were detected with the band values at $536 \mathrm{~cm}^{-1}$ (hematite for the sample ET-1) and $455 \mathrm{~cm}^{-1}$ 
(hematite and magnetite for the sample ET-6) [21,23]. Hematite was also detected by XRD for most of the samples, and its existence suggested that the potsherds should have been fired in an oxidizing atmosphere in which the iron transforms to hematite and gives the colors of brown and red shades $[9,27]$.

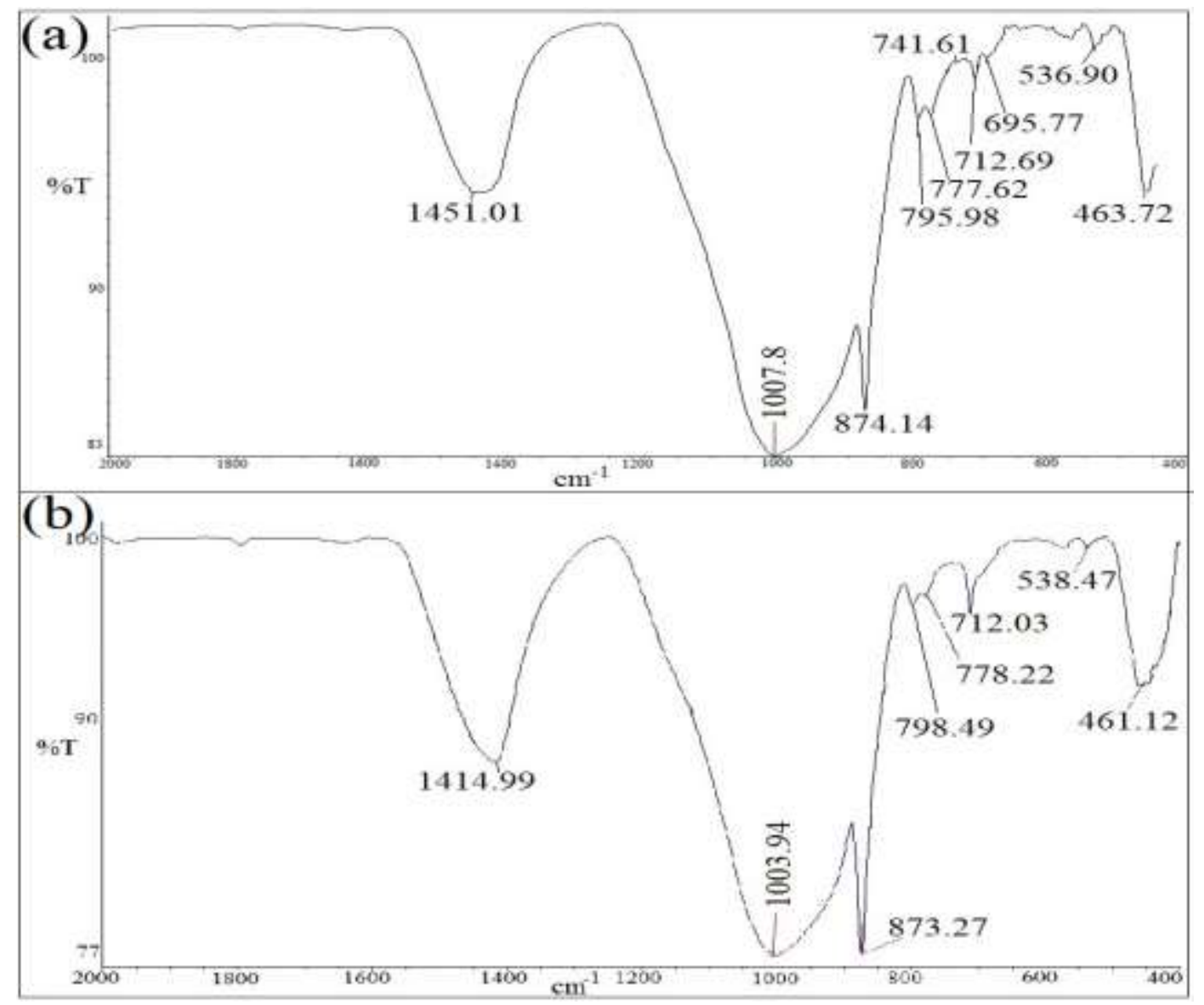

Figure 7. FTIR result of the sample (a) ET-1 and (b) ET-7

Table 4. FTIR results of the samples

\begin{tabular}{lll}
\hline $\begin{array}{l}\text { Sample } \\
\text { code }\end{array}$ & Evident band values $\left(\mathrm{cm}^{-1}\right)$ & Related minerals* \\
\hline ET-1 & $1451 / 1007 / 874 / 795 / 777 / 741 / 712 / 695 / 536 / 463$ & $\mathrm{Cal} / \mathrm{K}, \mathrm{I}, \mathrm{Or} / \mathrm{Cal}, \mathrm{Pr} / \mathrm{Q} / \mathrm{Q} / \mathrm{Al}, \mathrm{O}, \mathrm{Mc} / \mathrm{Cal} / \mathrm{Q} / \mathrm{H} / \mathrm{Cl}, \mathrm{I}, \mathrm{Mc}, \mathrm{Or}, \mathrm{Pr}$ \\
ET-2 & $1416 / 1004 / 872 / 798 / 712 / 455 / 435$ & $\mathrm{Cal} / \mathrm{K}, \mathrm{I}, \mathrm{Ol} / \mathrm{Cal}, \mathrm{Pr} / \mathrm{Q} / \mathrm{Cal} / \mathrm{Q}, \mathrm{I}, \mathrm{Cl} / \mathrm{K}, \mathrm{Cl}$ \\
ET-3 & $1427 / 1018 / 873 / 798 / 778 / 712 / 459$ & $\mathrm{Cal}, \mathrm{Do} / \mathrm{K}, \mathrm{Mc}, \mathrm{Ms} / \mathrm{Cal}, \mathrm{Pr} / \mathrm{Q} / \mathrm{Cal} / \mathrm{Q}, \mathrm{I}, \mathrm{Cl}$ \\
ET-4 & $1423 / 1010 / 970 / 916 / 872 / 712 / 463$ & $\mathrm{Cal} / \mathrm{K}, \mathrm{I}, \mathrm{Or} / \mathrm{Pr}, \mathrm{W} / \mathrm{Pr} / \mathrm{Cal}, \mathrm{Pr} / \mathrm{Cal} / \mathrm{Pr}, \mathrm{K}, \mathrm{I}, \mathrm{Cl}, \mathrm{Mc}, \mathrm{Or}$ \\
ET-5 & $1416 / 1004 / 872 / 796 / 778 / 712 / 446$ & $\mathrm{Cal} / \mathrm{K}, \mathrm{I}, \mathrm{Ol} / \mathrm{Cal}, \mathrm{Pr} / \mathrm{Q} / \mathrm{Cal} / \mathrm{K}, \mathrm{Cl}$ \\
ET-6 & $1423 / 996 / 873 / 798 / 712 / 575 / 455$ & $\mathrm{Cal} / \mathrm{Al}, \mathrm{I}, \mathrm{Ol}, \mathrm{Ms} / \mathrm{Cal}, \mathrm{Pr} / \mathrm{Q} / \mathrm{Cal} / \mathrm{H}, \mathrm{M} / \mathrm{Q}, \mathrm{I}, \mathrm{Cl}$ \\
ET-7 & $1414 / 1003 / 873 / 798 / 778 / 712 / 538 / 461$ & $\mathrm{Cal} / \mathrm{K}, \mathrm{I}, \mathrm{Ol} / \mathrm{Cal}, \mathrm{Pr} / \mathrm{Q} / \mathrm{Q} / \mathrm{Cal} / \mathrm{K}, \mathrm{Mc}, \mathrm{Or}, \mathrm{Pr}$ \\
\hline
\end{tabular}

*Al: Albite, Cal: calcite, $\mathrm{Cl}$ : chlorite, Do: Dolomite, H: hematite, I: Illite, K: kaolinite, M: magnetite, Mc: Microcline, Ms: muscovite, Ol: Oligoclase, Or: Orthoclase, Pr: Pyroxene, Q: quartz, W: Wollastonite

\subsubsection{Petrography results}

Quartz, plagioclase, opaque minerals and olivine were detected for the whole sample set, while chert and biotite were seen in most of the samples (Table 5). Pyroxene was determined for the samples ET-1, ET-3 and ET-7. The main rock type for the sample set was found as basalt which is an igneous rock formation. The presence of olivine suggested that the raw materials likely originated from mafic rocks containing $\mathrm{Mg}$ and Fe. Calcite was not detected for the samples, although it was found as the major phase for some of the samples (i.e. ET-2, ET-3, ET-5 and ET-6). This result would be attributed to the fact that determination of calcite could have been hindered owing to the fine calcite grains dispersing heterogeneously in the ceramic matrix, and such phenomenon might have occurred because of the 
chemical sedimentation during the generation of the clays. It should also be taken into account that the thin sections prepared for the analysis could be comprised of heterogonous grains of the minerals. Considering the XRD results, another factor can be the subsequent formation of high temperature phases of calcium silicates (gehlenite and/or pyroxene) after the decomposition of the carbonates (this assumption could be valid for the samples fired at relatively higher temperature ranges). Yet, the presence of the carbonates (i.e. calcite; primary or secondary) was well-established through the spectroscopic techniques, and petrography offered substantial information about the paste features, rock origin and the identification of other minerals.

Table 5. Petrography results of the samples

\begin{tabular}{lcccl}
\hline Sample & $\mathrm{P}$ & MTA & $\begin{array}{c}\text { Rock and } \\
\text { Minerals* }\end{array}$ & \multicolumn{1}{c}{ Definition } \\
\hline ET-1 & 6 & 45 & Q,Pl,Ch,Bi,Py,Ol,Op & $\begin{array}{l}\text { Fine aggregates. Rock origin of the } \\
\text { aggregates is basalt. }\end{array}$ \\
ET-7 & 4 & - & Q,Pl,Ch,Bi,Op,Ol & $\begin{array}{l}\text { Medium aggregates. Rock origin of the } \\
\text { aggregates is basalt }\end{array}$ \\
ET-4 & 8 & 35 & Q,Pl,Py,Op,B,Ol & $\begin{array}{l}\text { Medium aggregates. Rock origin of the } \\
\text { aggregates is basalt }\end{array}$ \\
ET-6 & & &
\end{tabular}

Fine / Medium / Coarse Aggregate (mm): <0,5 / 0,5-1,0 / >1,0; P: Porosity (vol. \%), MTA: Matrix Total Aggregate (vol. \%); * B: Basalt, Bi: Biotite, Ch: Chert, Ol: Olivine, Op: Opaque minerals, Pl: Plagioclase, Py: Pyroxene, Q: Quartz. (-): not defined.

The microphotographs of the samples showed that the ratio of non-plastic material/matrix was low in general (Figure 8 and Figure 9). The colors of the ceramic pastes again suggested that the potsherds were exposed to an oxidizing firing atmosphere in which oxygen has well-dispersed through the ceramic matrix resulting in brown and red shades. Some probable grog fragments were seen for some of the samples (e.g. ET-6; Figure 9b). Such residuals were thought to be the clay lumps and/or ground ceramic, tile or rock components which could be added to avoid the formation of cracks whilst the product was dried and/or fired [28-30]. In the microphotographs of some samples, the presence of irregular shaped gaps (relatively bigger and more distinguishable than the pores of the matrix) would be attributed to; $i$ : the calcite ghost, which may occur in case of acidic water exposure in the burial environment resulting in formation of such voids, $i i$ : the organic residues which may leave elongated voids after decomposition (or burning) [20] (Figure 8 b-d, Figure 9 a-c).
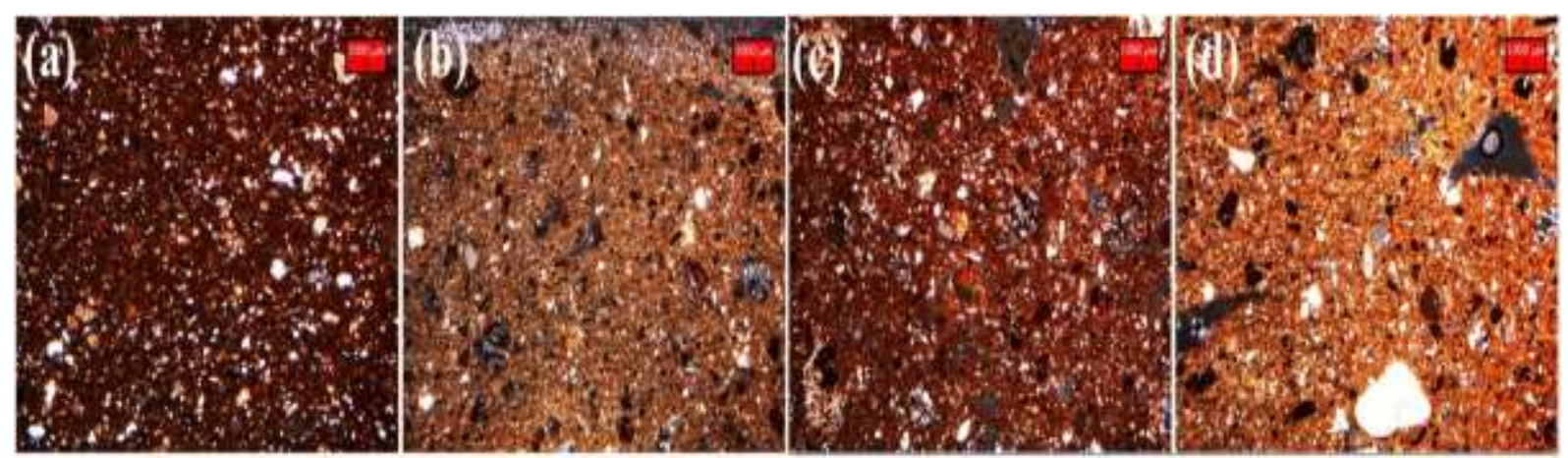

Figure 8. Thin section image of the sample (a) ET-1, (b) ET-2, (c) ET-3 and (d) ET-4 

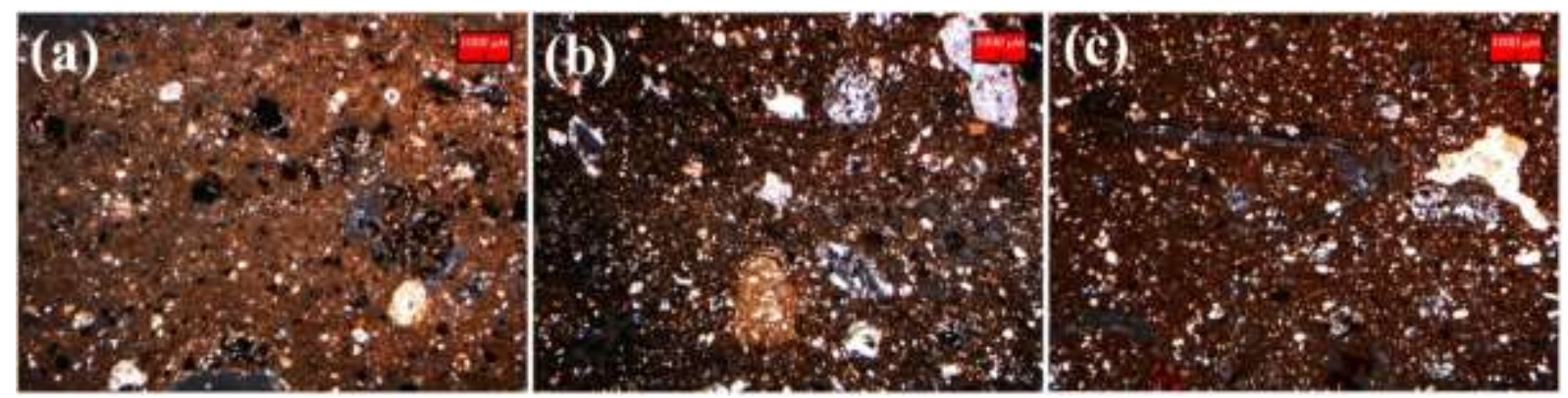

Figure 9. Thin section image of the sample (a) ET-5, (b) ET-6 and (c) ET-7

\subsection{Thermal Analysis (TG-DTA)}

DTA curves indicated that calcite was present in two forms; primary and secondary. Primary calcite was determined with the endothermic effect on DTA curve between $750-800^{\circ} \mathrm{C}$ (Figure $10 \mathrm{~b}$-c), while secondary calcite was observed with the endothermic effect around $720^{\circ} \mathrm{C}$ (Figure 10 a-d) (lower than that of primary calcite) [20]. The mass loss values were found as 1.03-3.41 wt .\% (25-200 $\left.{ }^{\circ} \mathrm{C}\right), 0.81-1.52$ wt $\%\left(200-400^{\circ} \mathrm{C}\right), 0.66-1.32$ wt $\%\left(400-600^{\circ} \mathrm{C}\right), 4.39-9.56 \mathrm{wt} . \%\left(600-850^{\circ} \mathrm{C}\right)$ and $0.04-0.38$ wt $\%$ $\left(850-1000^{\circ} \mathrm{C}\right)$. The mass loss in the range of $600-850^{\circ} \mathrm{C}$, at which the most prominent changes have appeared, was assigned to decomposition of calcite, and it was seen that the samples possessing calcite as the major phase (see Table 3) showed a clear evidence of primary calcite with both the endothermic effect and also the relatively higher mass loss $(9.56 \mathrm{wt}$ \% for ET-3 and $9.51 \mathrm{wt}$. \% for ET-5) at this temperature range $[4,20,31]$. The absence of enthalpy changes and ignorable mass loss (Table 6) after $900^{\circ} \mathrm{C}$ implied that the sinterization behavior was limited, and thus the firing temperature likely did not exceed this range [4]. TG-DTA results were seen to be consistent with the former results achieved through the spectroscopic and microscopic techniques.
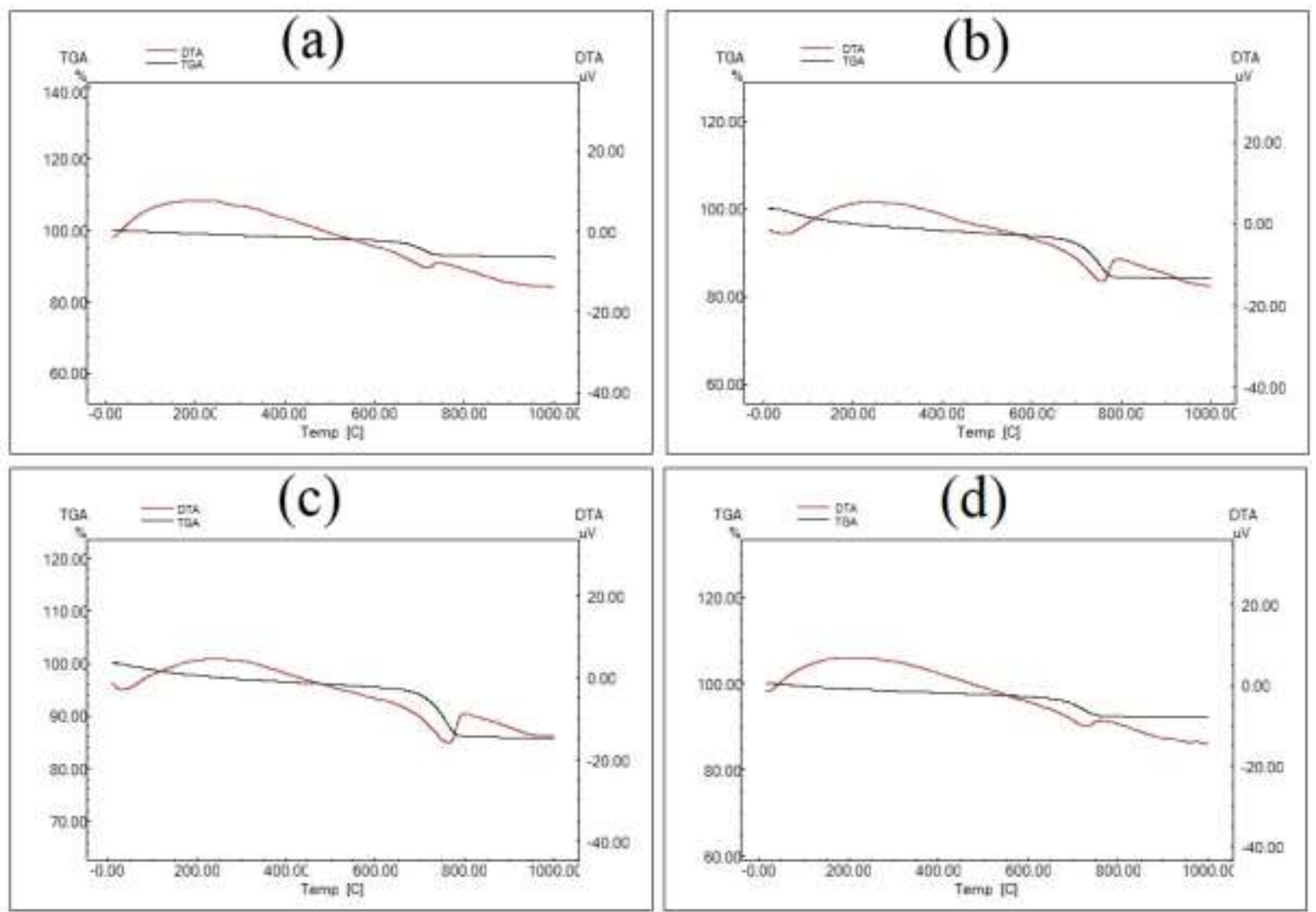

Figure 10. TG-DTA diagram of the sample (a) ET-1, (b) ET-3, (c) ET-5 and (d) ET-7 
Table 6. Mass loss values at certain temperature ranges

\begin{tabular}{lccccc}
\hline & \multicolumn{5}{c}{ Mass loss (wt. \%) } \\
\cline { 2 - 6 } Sample & $25-200^{\circ} \mathrm{C}$ & $200-400^{\circ} \mathrm{C}$ & $400-600^{\circ} \mathrm{C}$ & $600-850^{\circ} \mathrm{C}$ & $850-1000^{\circ} \mathrm{C}$ \\
\hline ET-1 & 1.03 & 0.93 & 0.97 & 4.39 & 0.35 \\
ET-2 & 1.45 & 0.94 & 1.27 & 6.22 & 0.17 \\
ET-3 & 3.41 & 1.52 & 1.24 & 9.56 & 0.18 \\
ET-4 & 1.35 & 0.95 & 1.32 & 6.82 & 0.32 \\
ET-5 & 2.24 & 1.22 & 0.99 & 9.51 & 0.16 \\
ET-6 & 1.44 & 0.81 & 0.66 & 6.36 & 0.38 \\
ET-7 & 1.19 & 0.92 & 0.93 & 4.68 & 0.04 \\
\hline
\end{tabular}

\section{Conclusions}

This study has dealt with the archaeometric characterization of Early Bronze Age plain simple wares (tripod vessels) of Tilbeshar (Turkey). It was intended to enlighten the raw material content and firing properties. Instead of using one or two methods for a large number of samples, a relatively smaller amount of samples clearly representing the mentioned ceramic group was investigated using multi analytical methods. It was seen that both the sampling method and the analytical techniques employed within the research were appropriate to reveal the production features of such potsherds.

The data obtained through various characterization techniques suggested that calcareous clay batches would have been used particularly due to higher amounts of $\mathrm{CaO}$. Additionally, calcite was detected by XRD, FTIR and TG-DTA. The differentiation of primary and secondary calcite was wellestablished by FTIR and TG-DTA analyses which showed the IR bands at higher wavelengths and enthalpy changes at relatively lower temperatures, respectively. The firing temperature of the potsherds was found to change in the range of $700-900^{\circ} \mathrm{C}$ in general, and the appearance of neo-formations in most of the samples indicated a temperature range of $800-900^{\circ} \mathrm{C}$ for such potsherds. The micro structural properties of the samples also approved the firing temperatures due to poor vitrification degree. Finally, the rock origin and mineralogical contents of the samples indicated to a local production (considering the geological formation of the region).

\section{Acknowledgements}

This study has been financially supported by Batman University, Department of Scientific Research Projects (BAP) with the project number BTUBAP-2017-Yüksek Lisans-3. We would like to thank the authorities of the labs where the analyses have been carried out; Bilecik Şeyh Edebali University Central Research and Application Laboratory (MARAL), Dicle University Science and Technology Application and Research Center (DÜBTAM) and Ankara University Geoscience Application and Research Center (YEBİM). We also gratefully thank Assoc. Prof. Dr. Ali Akın Akyol, Prof. Dr. Yusuf Kağan Kadığlu, Res. Assist. Dr. Kıymet Deniz and Gülşen Albuz Geren. This manuscript covers the data of a master thesis (Didem Çağine; Batman University, Institute of Science, Department of Archaeometry).

\section{References}

[1] Genç E. 2018. Doğanpınar Barajı Tilbaşar Höyük 2016 yılı kazısı. 39. Kazı Sonuçları Toplantısı, 1: 159-172, 22-26 May1s 2017, Bursa.

[2] Tilbaşar Höyük kazı arşivi. 2018.

[3] Kepinski C., Bulgan F. 2007. Research at Tilbeshar in 2005 City from the Early and Middle Bronze Ages. 28. Kazı Sonuçları Toplantısı, 2: 733-742, 29 Mayıs-2 Haziran 2006, Çanakkale.

[4] Krapukaityte A., Tautkus S., Kareiva A., Zalieckiene E. 2008. Thermal Analysis - A powerful tool for the characterization of pottery. Chemija, 19 (2): 4-8.

[5] Merkevicius A., Bezdicka P., Juskenas R., Kiuberis J., Senvaitiene J., Pakutinskiene I., Kareiva A. 2007. XRD and SEM characterization of archeological findings excavated in Lithuania. Chemija, 18: 36-39. 
[6] Bayazit M., Işık I., Issi, A. 2015. Investigating the firing technologies of Part-Roman potsherds excavated from Kuriki (Turkey) using thermal and vibrational spectroscopic techniques. Vibrational Spectroscopy, 78: 1-11.

[7] Bayazit M. 2018. Archaeometric study of possible Ninevite-5 pottery from upper Tigris region using SEM-EDS, PEDXRF and OM. X-Ray Spectrometry, 47: 92-104.

[8] Loehman R.E. 1993. Characterization of Ceramics. Butterworth-Heinemann. 295p. Reed-Elsevier Inc.

[9] Issi A., Raškovska A., Kara A., Grupce O., Minčeva-Šukarova B., Okyar F. 2011. Scanning electron microscopy and micro-Raman spectroscopy of slip layers of Hellenistic ceramic wares from Dorylaion/Turkey. Ceram. Int., 37: 1879-1887.

[10] MTA. 2018. http://www.mta.gov.tr/v3.0/sayfalar/hizmetler/maden-haritalari/kahramanmaras.pdf (Accessed date: 04.12.2018).

[11] MTA. 2018. http://www.mta.gov.tr/v3.0/sayfalar/hizmetler/maden-haritalari/sanliurfa.pdf (Accessed date: 04.12.2018).

[12] MTA. 2018. http://www.mta.gov.tr/v3.0/sayfalar/hizmetler/maden-haritalari/osmaniye.pdf (Accessed date: 04.12.2018).

[13] MTA. 2018. http://www.mta.gov.tr/v3.0/sayfalar/hizmetler/maden-haritalari/Antakya.pdf (Accessed date: 04.12.2018).

[14] MTA. 2018. http://www.mta.gov.tr/v3.0/sayfalar/hizmetler/maden-haritalari/gaziantep.pdf (Accessed date: 04.12.2018).

[15] MTA. 2018. http://www.mta.gov.tr/v3.0/sayfalar/hizmetler/maden-haritalari/kilis.pdf (Accessed date: 04.12.2018).

[16] MTA. 2018. http://www.mta.gov.tr/v3.0/sayfalar/hizmetler/maden-haritalari/adiyaman.pdf (Accessed date: 04.12.2018).

[17] Cultrone G., Rodriguez-Navarro C., Sebastian E., Cazalla O., De La Torre M.J. 2001. Carbonate and silicate phase reactions during ceramic firing. Eur. J. Mineral., 13: 621-634.

[18] Iordanidis A., Garcia-Guinea J., Karamitrou-Mentessidi G. 2009. Analytical study of ancient pottery from the archaeological site of Aiani, northern Greece. Mater. Charact., 60: 292-302.

[19] Shoval S, Beck P, Yadin E. 2006. The ceramic technology used in the manufac-ture of Iron Age pottery from Galilee. In: Maggetti M, Messiga B, editors. Geomaterials in cultural heritage, vol. 257. London: The British Geological Society Publishing House, 101-117.

[20] Fabbri B., Gualtieri S., Shoval, S. 2014. The presence of calcite in archeological ceramics. J. Eur. Ceram. Soc., 34: 1899-1911.

[21] Farmer V.C. 1974. Infrared Spectra of Minerals, Mineralogical Society, 539p. London.

[22] Afremow L.C., Vandeberg J.T. 1966. High resolution spectra of inorganic pigments and extenders in the mid infrared region from $1500 \mathrm{~cm}-1$ to $200 \mathrm{~cm}-1$. J. Paint Technol., 38: 169-202.

[23] Kieffer S.W. 1979. Thermodynamics and lattice vibrations of minerals: 2. Vibrational characteristics of silicates. Rev. Geophys. Space Phys., 17: 20-34.

[24] Shoval S. 2003. Using FT-IR spectroscopy for study of calcareous ancient ceramics. Optical Materials, 24: 117-122.

[25] Dowty E. 1987. Vibrational interaction of tetrahedra in silicate glasses and crystals: II. Calculation on melilites, piroxenes, silica polymorphs and feldspars. Phys. Chem. Minerals, 14: 122-138.

[26] Rutstein M.S., White W.B. 1971. Vibrational spectra of high-calcium piroxenes and piroxenoids. Am. Mineral., 56: 877-887.

[27] Van der Weerd J., Smith G.D., Firth S., Clark R.J.H. 2004. Identification of black pigments on prehistoric Southwest American potsherds by infrared and Raman microscopy, J. Archaeol. Sci., 31: 1429-1437.

[28] Loftfield T.C. 1976. A Brief and True Report: An Archaeological Interpretation of the Southern North Carolina Coast (Unpublished Ph.D. dissertation) Department of anthropology, University of North Carolina, Chapel Hill.

[29] Saffer M. 1979. Aboriginal Clay Resource Utilization of the Georgia Coast (M.A. thesis) Department of anthropology, University of Florida, Gainesville.

[30] Rice P.M. 1987. Pottery analysis: A sourcebook, University of Chicago Press, 584p. Chicago.

[31] Meyvel S., Sathya P., Velraj G. 2012. Thermal characterization of archaeological pot sherds recently excavated in Nedunkur, Tamilnadu, India. Cerâmica, 58: 338-341. 